\title{
Pengaruh Budaya Organisasi dan Komitmen Organisasi terhadap Kinerja Pegawai di PT. Garuda Indonesia Tbk
}

\author{
Alberta Dwi Setyorini ${ }^{1}$ \\ Program Doktor Service Management \\ Universitas Trisakti, Indonesia
}

\author{
Santi $^{2}$ \\ Fakultas Manajemen \\ STIE Bisma Lepisi, Indonesia
}

\author{
Sarfilianty Anggiani ${ }^{3}$ \\ Fakultas Ekonomi dan Bisnis \\ Universitas Trisakti, Indonesia
}

\begin{abstract}
Surel : alberthads2017@yahoo.com
\end{abstract}
\section{ABSTRAK}

Tujuan penelitian ini adalah untuk menganalisis pengaruh dari budaya organisasi dan komitmeJn organisasi terhadap kinerja pegawai di PT. Garuda Indonesia Tbk. Data yang digunakan dalam penelitian ini adalah data primer dengan metode pengumpulan data yaitu melalui penyebaran kuisioner. Sampel dalam penelitian ini sebanyak 60 orang pegawai di PT. Garuda Indonesia Tbk. Teknik analisis dalam penelitian ini melalui Analisis Regresi Linier Berganda. Hasil analisis membuktikan budaya organisasi dan komitmen organisasi secara simultan berpengaruh signifikan terhadap kinerja pegawai di PT. Garuda Indonesia Tbk. Budaya Organisasi dan komitmen organisasi secara parsial berpengaruh positif dan signifikan terhadap kinerja pegawai di PT. Garuda Indonesia Tbk.

Kata Kunci: $\quad$ Budaya Organisasi; Komitmen Organisasi; Kinerja Pegawai.

The Influence of Organizational Culture and Organizational Commitment on Employee Performance at PT. Garuda Indonesia Tbk

\section{ABSTRACT}

The purpose of this study was to analyze the influence of organizational culture and organizational commitment on employee performance at PT. Garuda Indonesia Tbk. The data used in this study are primary data with data collection methods, namely through questionnaires. The sample in this study were 60 employees at PT. Garuda Indonesia Tbk. The analysis technique in this research is through Multiple Linear Regression Analysis. The results of the analysis prove that organizational culture and organizational commitment simultaneously have a significant effect on employee performance at PT. Garuda Indonesia Tbk. Organizational culture and organizational commitment partially have a positive and significant effect on employee performance at PT. Garuda Indonesia Tbk.

Keywords: Organizational Culture; Organizational Commitment; Employee Performance.

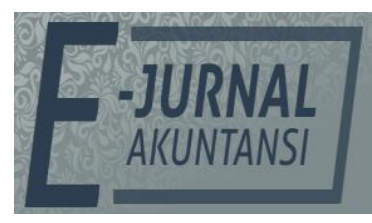

e-ISSN 2302-8556

Vol. 31 No. 2

Denpasar, Februari 2021 Hal. 427-437

DOI:

10.24843/EJA.2021.v31.i02.p13

PENGUTIPAN:

Setyorini, A.D., Santi, \& Anggiani, S. (2021).

Pengaruh Budaya Organisasi dan Komitmen Organisasi terhadap Kinerja Pegawai di PT. Garuda Indonesia Tbk.

E-Jurnal Akuntansi, 31(2), 427-437

RIWAYAT ARTIKEL: Artikel Masuk: 5 Januari 2021 Artikel Diterima: 21 Januari 2021

Artikel dapat diakses : https://ojs.unud.ac.id/index.php/Akuntansi/index 


\section{PENDAHULUAN}

Indonesia menduduki peringkat keempat sebagai negara dengan jumlah penduduk terbanyak di dunia. Kondisi ini menjadikan Indonesia sebagai pasar yang potensial bagi dunia usaha, salah satunya bagi usaha industri jasa penerbangan. Industri jasa penerbangan merupakan salah satu sektor industri yang memiliki pangsa pasar terbesar di dunia. Pertumbuhan industri jasa penerbangan juga relatif pesat dari tahun ke tahun. Hal ini dibuktikan dengan data Badan Pusat Statistik, (2016) yang mencatat adanya volume peningkatan jumlah penumpang transportasi udara terangkut di Indonesia di tahun 2015 yang mencapai 76.628.867 jiwa dan di tahun 2016 yang mencapai 89.358.457 jiwa. Meningkatnya jumlah masyarakat yang menggunakan transportasi udara secara langsung berdampak pada persaingan antar maskapai penerbangan yang kini semakin giat dalam meningkatkan pangsa pasar.

Menurut data dari Direktorat Jenderal Perhubungan Udara Kementrian Perhubungan Republik Indonesia, (2017), jumlah perusahaan maskapai penerbangan niaga berjadwal yang masih beroperasi sebanyak 13 buah dan jumlah perusahaan maskapai penerbangan niaga tidak berjadwal yang beroperasi sebanyak 44 buah. Banyaknya jumlah perusahaan maskapai penerbangan yang beroperasi di Indonesia secara langsung menciptakan persaingan yang ketat.

Salah satu maskapai penerbangan nasional milik BUMN yaitu Garuda Indonesia yang mengoperasikan 202 pesawat dengan mengoperasikan sebanyak 144 pesawat terbaru sedangkan anak perusahaan Citilink airlines mengoperasikan 58 pesawat. Selain itu Garuda Indonesia memiliki rute penerbangan 69 destinasi domestik dan 22 destinasi internasional. Garuda Indonesia bergabung dengan jaringan airlines besar di dunia yaitu SkyTeam. Komitmen Garuda Indonesia dalam melayani pelanggan dalam hal keamanan, ketepatan waktu, keramahan, dan profesional menjadi keunggulan terbaik dibandingkan airlines lainnya. PT Garuda Indonesia Tbk. adalah maskapai pertama dan terbesar di Indonesia dengan pendekatan berorientasi "melayani", Garuda Indonesia bertujuan menjadi penyedia layanan terdepan bagi wisatawan domestik dan macannegara sekaligus menyediakan layanan pengiriman barang melalui udara. Perkembangan yang dialami Garuda Indonesia tercermin dengan perusahaan memperoleh titel sebagai most improved airline (perusahaan penerbangan yang paling banyak mengalami perbaikan) dari Skytrax, lembaga pengkajian penerbangan udara dunia.

Mengingat semakin meningkatnya persaingan pada industri jasa penerbangan, maka kinerja pegawai menjadi salah satu hal yang harus diperhatikan. Jika kinerja pegawai baik maka tujuan perusahaan akan tercapai dan sebaliknya apabila kinerja pegawai menurun mengakibatkan pekerjaan menjadi tidak selesai tepat pada waktunya yang akan berdampak bagi perkembangan dan kemajuan organisasi (Okwa, 2011). Tujuan suatu organisasi akan tercapai dengan baik apabila mempuyai pegawai atau sumber daya manusia yang berkualitas (Mathis \& Jackson, 2006). Maka dalam menciptakan kinerja yang baik dalam organisasi tergantung pada kinerja pegawai yang bergerak menjalankan tujuan organisasi tersebut. Pegawai bukan hanya menjadi 
objek dalam pencapaian keberhasilan sebuah organisasi namun juga sebagai pelaku keberhasilan organisasi tersebut.

Sumber daya manusia menjadi komponen utama bagi setiap perusahaan untuk mencapai tujuannya. Pengelolaan yang baik dilakukan tidak hanya untuk mencapai kinerja finansial dari sisi perusahaan, namun juga tujuan karyawan sebagai bagian dari perusahaan. Kekuatan sumber daya manusia dibentuk oleh karakter atau perilaku yang dimiliki oleh setiap karyawan serta lingkungan dalam perusahaan. Perhatian yang besar pada pengembangan pada SDM diharapkan menjadi sebuah proses untuk menjaga dan meningkatkan kualitas, sehingga berdampak pada meningkatnya kinerja perusahaan dimana karyawan tersebut berada. Kinerja karyawan yang tinggi akan berimplikasi langsung pada perusahaan, maka perhatian pihak manajemen tertuju pada bagaimana meningkatkan kinerja karyawan.

Menurut Wibowo, (2012), faktor penentu kinerja pegawai, yaitu atribusi yang bersifat internal dan eksternal. Faktor internal seperti bakat, kemampuan, kemauan, dan upaya. Sedangkan faktor eksternal terdiri atas budaya organisasi, pemimpin, dan rekan kerja. Oleh karena itu, agar pegawai sebaga individu yang ada di dalam sebuah organisasi memiliki kualitas kinerja yang bagus, organisasi harus memperhatikan secara tepat dengan menghargai bakat-bakat pegawai, kemmapuan pegawai, serta membimbing pegawai secara tepat.

Salah satu faktor yang menentukan kinerja pegawai adalah budaya organisasi, maka budaya organisasi harus sangat diperhatikan(Eric et al., 2010). Suatu organisasi terbentuk dari kumpulan individu yang berbeda baik sifat, karakter, keahlian, pendidikan, dan latar belakang pengalaman dalam hidupnya. Dengan demikan perlu ada pengakuan pandangan yang akan berguna untuk pencapaian misi dan tujuan organisasi tersebut, agar tidak berjalan sendirisendiri. Diperlukan pengertian yang jelas dan perhatian terhadap budaya organisasi untuk dapat mengelola organisasi dengan baik (Victoria, 2010). Nilai inti organisasi akan dipegang secara intensif dan dianut secara meluas dalam suatu budaya yang kuat. Oleh karena itu, budaya organisasi memiliki pengaruh yang sangat besar pada aspek-aspek fundamental dari kinerja pegawai (Ibrahim et al., 2012). Pernyataan tersebut telah diterima dengan luas dan didukung oleh beberapa penelitian yang menghubungkan kinerja pegawai dengan budaya organisasi.

Setiap karyawan juga mempunyai nilai dan tujuan sendiri sehingga diperlukannya suatu integrasi antara tujuan individu dengan tujuan organisasi (Javad \& Davood, 2012). Dalam mengusahakan integrasi antara tujuan organisasi dengan tujuan individu karyawan, perusahaan perlu untuk mengetahui kebutuhan-kebutuhan yang menjadi kebutuhan dari masingmasing karyawan (Vincent \& Dareen, 2007). Dengan demikian kebutuhan karyawan yang diharapkan akan terpenuhi melalui komitmen organisasi menjadikan kebutuhan organisasi akan kinerja karyawan akan juga dapat tercapai (Sinem \& Asikgil, 2011). Hal ini dikarenakan apabila seorang karyawan yang sudah dipenuhi akan kebutuhannya maka karyawan tersebut juga akan memiliki komitmen yang tinggi pada perusahaanya. Dengan adanya komitmen organisasi pada karyawan yang tinggi akan membuat karyawan 
bekerja lebih optimal, dan kinerja yang dihasilkan oleh karyawan akan juga meningkat secara positif pada perusahaannya.

Menurut Wibowo, (2012) kinerja mempunyai makna yang luas, bukan hanya sebagai hasil kerja tetapi juga bagaimana proses kerja berlangsung. Kinerja adalah tentang melakukan pekerjaan dan hasil yang dicapai dari pekerjaan tersebut (Yousef, 2000). Kinerja merupakan hasil kerja secara kualitas maupun kuantitas yang dicapai oleh seseorang dalam melaksanakan tugas yang diberikan kepadanya sesuai dengan standar/kriteria yang telah ditetapkan (Mangkunegara, 2013). Dengan kata lain, karyawan yang berkinerja tinggi memiliki makna bahwa karyawan tersebut berhasil menjalankan tugas dan tanggung jawab yang dibebankan kepadanya. Semakin tinggi kinerja pegawai, maka produktivitas oranisasi secara keseluruhan akan meningkat (Taurisa, C. M. et al., 2012). Ada banyak faktor yang dapat mempengaruhi kinerja seorang karyawan, dalam penelitian ini difokuskan pada faktor organisasi yaitu budaya organisasi, dan faktor internal yaitu komitmen organisasional.

Menurut Robbins, (2015), secara komprehensif budaya organisasi didefenisikan sebagai pola asumsi dasar bersama yang dipelajari oleh kelompok dalam suatu organisasi sebagai alat untuk memecahkan masalah terhadap penyesuaian faktor eksternal dan integrasi faktor internal dan telah terbukti sah. Budaya organisasi memiliki peran utama dalam membentuk perilaku karyawan. Sebagai sebuah sistem nilai, budaya organisasi merupakan nilai-nilai dan sikap-sikap yang telah diyakini karyawan sehingga telah menjadi dasar perilaku dan sikap karyawan ketika bekerja (Syed, 2010). Sikap-sikap dan nilainilai yang telah mengkristal dalam organisasi akan menjadi pedoman karyawan untuk berpikir, bersikap, dan berperilaku sesuai dengan sikap dan nilai yang diyakini (Sabri \& Ullah, 2012). Dengan kata lain, budaya akan mempengaruhi sejauhmana anggota organisasi dalam mencapai tujuan organisasi (Mega \& Surya, 2016).

Budaya organisasi merupakan filosofi dasar organisasi yang memuat keyakinan, norma-norma, dan nilai-nilai bersama menjadi karakteristik inti tentang bagaimana melakukan sesuatu dalam sebuah organisasi (Tintami et al., 2013). Mangkunegara, (2011) menguraikan kinerja merupakan pencapain hasil kerja karyawan secara kualitas dan kuantitas dalam menyelesaikan tugas dan tanggung jawab yang telah diberikan.

Hasil penelitian Khaliq, (2015), Aziz, (2018), Suharto, S., \& Nusantoro, (2018), dan Rosyidah et al., (2018) menyatakan bahwa budaya organisasi termasuk nilai dan norma yang diterapkan terhadap karyawan dapat mempengaruhi tingkat kinerja karyawan secara efektif. Hasil tersebut didukung dengan pengujian statistik yang membuktikkan bahwa berpengaruh positif dan signifikan indikator budaya organisasi terhadap kinerja karyawan (Seyyed, 2013). Berdasarkan uraian tersebut penelitian ini menduga sebagai berikut.

$\mathrm{H}_{1}$ : Budaya organisasi berpengaruh positif terhadap kinerja pegawai.

(Sopiah, 2008) mengemukakan bahwa komitmen organisasional adalah gabungan dari tiga dimensi perilaku yang dapat digunakan untuk menilai tingkat kecenderungan karyawan untuk tetap bertahan sebagai anggota organisasi, atau memiliki karir jangka panjang di dalam organisasi. 
Komitmen organisasional merupakan identifikasi dam keterlibatan seseorang yang relatif kuat terhadap organisasasi. Artinya, seorang karyawan yang memiliki komitmen tinggi memiliki keinginan yang kuat untuk tetap mempertahankan keanggotaannya dalam organisasi dan bersedia bekerja keras bagi pencapaian tujuan organisasi.

Sebagai bentuk refleksi dari sikap karyawan, kedekatan emosional dan bentuk perhatian karyawan terhadap organisasinya untuk untuk mencapai keberhasilan dan keberlanjutan suatu organisasi Luthans, (2012), komitmen sudah dianggap sebagai salah satu sikap karyawan yang banyak mendapatkan perhatian peneliti di bidang perilaku organisasi. Sutrisno et al., (2018) menyatakan bahwa komitmen organisasional terbentuk karena adanya kepercayaan, kemauan dan keinginan untuk mencapai suatu tujuan agar dapat mempertahankan eksistensinya sebagai bagian dari organisasi dalam kondisi baik ataupun buruk. Komitmen berperan penting pada kinerja karyawan Ramadhan, (2017) yang dapat menjadi motivasi atau mendorong seseorang untuk bertanggung jawab terhadap kewajibannya (Brodoastuti, 2016), sehingga karyawan dapat menghadapi setiap tantangan dan kesulitan yang dihadapinya. Berdasarkan uraian tersebut maka hipotesis penelitian yang diajukan adalah sebagai berikut.

$\mathrm{H}_{2}$ : Komitmen organisasi berpengaruh positif terhadap kinerja pegawai.

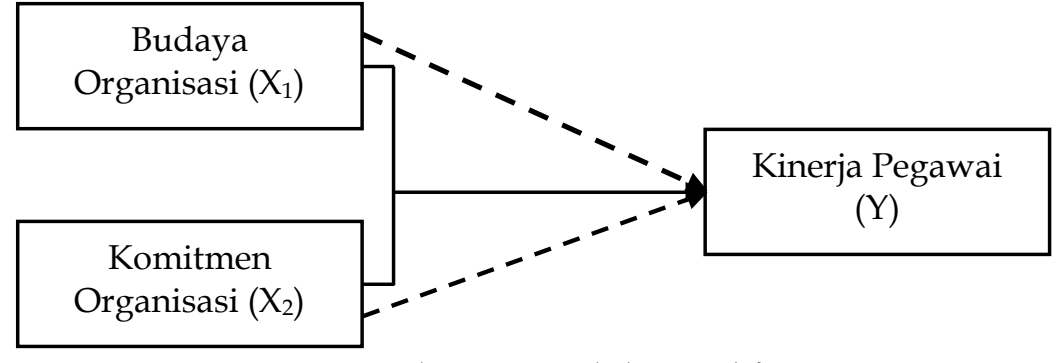

Gambar 1. Model Peneltian

Sumber: Data Penelitian, 2020

\section{METODE PENELITIAN}

Penelitian ini merupakan jenis penelitian kuantitatif dengan menggunakan data primer melalui survey terhadap sejumlah pegawai dengan melakukan penyebaran kuesioner kepada responden. Objek penelitian ini dilakukan di PT. Garuda Indonesia Tbk. Variabel yang diteliti meliputi Budaya Organisasi, Komitmen Organisasi, dan Kinerja Pegawai. Sampel dalam penelitian ini adalah sebanyak 60 pegawai yang didapat dari perhitungan rumus Slovin. Teknik sampling yang digunakan dalam penelitian ini adalah non-probability sampling dengan purposive sampling. Penyebaran kuesioner dilakukan secara langsung kepada pegawai darat yang berstatus pegawai tetap dengan minimal masa kerja satu tahun. Data pada penelitian ini dianalisis menggunakan SPSS. Teknik analisis menggunakan metode Analisis Regresi Linier Berganda. Penelitian korelasi sendiri dapat diartikan sebagai penelitian yang dilakukan oleh peneliti untuk mengetahui tingkat hubungan antara dua variabel atau lebih, tanpa melakukan perubahan, tambahan, atau manipulasi terhadap data yang memang sudah ada. Hasil penelitian tersebut dinyatakan dengan angka-angka 
dan persamaan statistik. Adapun persamaan regresi pada model penelitian ini adalah sebagai berikut.

$$
Y=\alpha+\beta_{1} X_{1}+\beta_{2} X_{2}+\varepsilon
$$

Keterangan:

$$
\begin{array}{ll}
\mathrm{Y} & =\text { Kinerja Pegawai } \\
\alpha & =\text { Konstanta } \\
\beta_{1} \text { dan } \beta_{2} & =\text { Koefesien regresi } \\
X_{1} & =\text { Budaya Organisasi } \\
X_{2} & =\text { Komitmen Organisasi } \\
\varepsilon & =\text { Kesalahan (error) }
\end{array}
$$

\section{HASIL DAN PEMBAHASAN}

Responden dalam penelitian ini adalah 60 orang pegawai PT. Garuda Indonesia Tbk secara random. Peneliti melakukan analisa terhadap demografi responden berdasarkan 3 kriteria yaitu: Jenis Kelamin, Usia dan juga Tingkat pendidikan. Karakteristik Responden Berdasarkan Jenis Kelamin dapat dilihat pada Tabel 1, berikut.

Tabel 1. Karakteristik Responden Berdasarkan Jenis Kelamin

\begin{tabular}{lcc}
\hline Gender & Jumlah responden & Persentase \\
\hline Pria & 20 & 33.33 \\
Wanita & 40 & 66.67 \\
Total & 60 & 100.00 \\
\hline
\end{tabular}

Sumber: Data Penelitian, 2020

Berdasarkan Tabel 1, mayoritas responden adalah wanita dengan persentase 66.67 persen atau berjumlah 40 orang, sedangkan untuk responden pria adalah sebanyak 20 responden atau 33.33 persen.

Tabel 2. Karakteristik Responden Berdasarkan Usia

\begin{tabular}{lcc}
\hline Usia & Jumlah Responden & Persentase \\
\hline $22-27$ & 26 & 43.33 \\
$28-35$ & 18 & 30.00 \\
$36-45$ & 9 & 15.00 \\
$46-55$ & 7 & 11.67 \\
Total & 60 & 100 \\
\hline
\end{tabular}

Sumber: Data Penelitian, 2020

Berdasarkan Tabel 2, yang dikelompokkan dalam usia, menunjukkan bahwa usia 22-27 adalah yang paling dominan dari pegawai PT. Garuda Indonesia Tbk dengan persentase sebesar 43.33 persen disusul kemudian di kelompok usia 28-35 tahun dengan 18 responden atau 30 persen, lalu kelompok usia 36-45 dengan 9 responden atau 15 persen dan yang terakhir kelompok usia 46-55 tahun dengan 7 responden atau 11.67 persen.

Tabel 3. Karakteristik Responden Berdasarkan Tingkat Pendidikan

\begin{tabular}{lcc}
\hline Tingkat Pendidikan & Jumlah Responden & Persentase \\
\hline S1 & 50 & 83.33 \\
S2 & 10 & 16.67 \\
Total & 60 & 100 \\
\hline
\end{tabular}

Sumber: Data Penelitian, 2020 
Berdasarkan Tabel 3, mayoritas responden memiliki jenjang akademik S1 dengan 50 responden atau sebanyak 83.33 persen dari total responden, sedangkan untuk jenjang pendidikan tinggi S2 yaitu 10 responden atau sebanyak 16.67 persen.

Analisis regresi berganda merupakan model yang digunakan untuk menganalisis pengaruh lebih dari satu variabel independen terhadap satu variabel dependen. Analisis regresi linier berganda diolah dengan menggunakan software Statistical Package for Social Sciences (SPSS). Hasil analisis regresi linier berganda disajikan pada Tabel 4 .

Tabel 4. Hasil Analisis Regresi Linier Berganda

\begin{tabular}{|c|c|c|c|c|c|}
\hline \multirow[b]{2}{*}{ Model } & \multicolumn{2}{|c|}{$\begin{array}{l}\text { Unstandardized } \\
\text { Coefficients }\end{array}$} & \multirow{2}{*}{$\begin{array}{c}\begin{array}{c}\text { Standardized } \\
\text { Coefficients }\end{array} \\
\text { Beta }\end{array}$} & \multirow[b]{2}{*}{$\mathrm{t}$} & \multirow[b]{2}{*}{ Sig. } \\
\hline & $\mathrm{B}$ & Std. Error & & & \\
\hline $1 \quad$ (Constant) & 2.509 & .721 & & 3.480 & .001 \\
\hline $\begin{array}{l}\text { Budaya } \\
\text { Organisasi }\end{array}$ & .365 & .112 & .398 & 3.251 & .002 \\
\hline $\begin{array}{l}\text { Komitmen } \\
\text { Organisasi }\end{array}$ & .023 & .138 & .020 & .165 & .036 \\
\hline Adjusted $\mathrm{R}^{2}$ & 0,709 & & & & \\
\hline $\mathrm{F}$ & 5,290 & & & & \\
\hline F Sig & 0,000 & & & & \\
\hline
\end{tabular}

Sumber: Data Penelitian, 2020

Berdasarkan Tabel 4, dapat disusun persamaan regresi sebagai berikut.

$$
\mathrm{Y}=2,509+0,365 \mathrm{X}_{1}+0,023 \mathrm{X}_{2}
$$

Nilai konstanta sebesar 2,509 menyatakan bahwa apabila variabel budaya orgnisasi $\left(X_{1}\right)$ dan komitmen organisasi $\left(X_{2}\right)$ sama dengan nol, maka kinerja pegawai $(\mathrm{Y})$ adalah sebesar 2,509 satuan.

Nilaikoefisien regresi dari budaya orgnisasi $\left(X_{1}\right)$, sebesar 0,365 menunjukan bahwa terdapat pengaruh positif antara variabel budaya organisasi terhadap kinerja pegawai. Hal ini berarti apabila variabel independen budaya organisasi meningkat sebesar 1 satuan dengan asumsi bahwa variabel bebas lainnya konstan, maka variabel kinerja pegawai akan mengalami peningkatan sebesar 0,365 .

Nilai koefisien regresi dari komitmen organisasi $\left(X_{2}\right)$, sebesar 0,023 menunjukan bahwa terdapat pengaruh positif antara variabel komitmen organisasi terhadap kinerja pegawai. Hal ini berarti apabila variabel independen komitmen organisasi meningkat sebesar 1 satuan dengan asumsi bahwa variabel bebas lainnya konstan, maka variabel kinerja pegawai akan mengalami peningkatan sebesar 0,023.

Berdasarkan hasil analisis regresi pada Tabel 4, variabel independen berpengaruh serempak (simultan) terhadap variabel dependen. Signifikansi F sebesar 0.000 lebih kecil dari 0,05. Hasil uji $\mathrm{F}$ yang di analisis dengan menggunakan program SPSS diperoleh nilai F hitung sebesar 5,290 dengan signifkansi sebesar 0,000 $<0,05$, maka dapat disimpulkan bahwa pada kelompok yang diuji memiliki perbedaan yang nyata (signifikan). Hasil ini mempunyai arti bahwa secara simultan ada pengaruh signifikan antara budaya organisasi dan komitmen organisasi terhadap kinerja pegawai. 
Hasil dari pengujian signifikansi secara parsial (Uji-t) yang ditunjukkann pada Tabel 4, menunjukkan bahwa koefisien budaya organisasi sebesar 0,365 dengan nilai probabilitas (nilai sig) 0,000. Nilai sig. $0.000<0.05$, sehingga dapat disimpulkan bahwa budaya organisasi berpengaruh positif dan signifikan terhadap kinerja pegawai. Dengan demikian hipotesis yang diajukan adalah menerima $\mathrm{H}_{1}$.

Hubungan budaya organisasi dengan Kinerja Pegawai. Hasil analisis regresi linier berganda menunjukkan bahwa budaya organisasi dapat mempengaruhi secara positif terhadap kinerja pegawai. Hal ini mengkonfirmasikan faktor-faktor dari budaya organisasi sebagai sekumpulan nilai-nilai yang diyakini bersama dapat menjadi pengikat organisasi dengan karyawan. Ikatan yang kuat ini dapat memotivasi karyawan untuk memberikan daya dan upayanya secara maksimal sehingga kinerja karyawan dapat menjadi maksimal. Hasil temuan ini sesuai dengan penelitian sebelumnya bahwa budaya organisasi mempengaruhi kinerja karyawan (Khaliq, 2015), (Aziz, 2018), (Suharto, S., \& Nusantoro, 2018) dan (Rosyidah et al., 2018).

Pihak manajemen PT. Garuda Indonesia Tbk. menyadari bahwa budaya budaya organisasi merupakan salah satu faktor yang dapat memengaruhi kinerja pegawai. Kinerja pegawai yang baik akan diikuti dengan meningkatnya kinerja perusahaan. Hal ini mendorong pihak manajemen PT Garuda Indonesia Tbk. untuk menanamkan nilai- nilai budaya organisasi kepada para pegawai dengan baik supaya tujuan perusahaan dapat dicapai. Di PT Garuda Indonesia Tbk. budaya organisasi telah dipahami dengan baik oleh para pegawai. Pemahaman budaya organisasi yang baik ini dapat dicapai dengan sosialisasi yang dilakukan oleh pihak manajemen kepada para pegawai secara terus-menerus. Sosialisasi mengenai budaya organisasi yang dilakukan oleh pihak manajemen didesai sedemikian rupa supaya dapat dipahami dengan mudah oleh para pegawai.

Berdasarkan persamaan yang diperoleh diketahui bahwa budaya organisasi merupakan faktor dominan mempengaruhi kinerja dibandingkan komitmen organisasi. Hal ini memberikan makna bahwa upaya meningkatkan kinerja karyawan dapat diprioritaskan pada peningkatan pemahaman dan keyakinan karyawan pada nilai-nilai budaya, dan secara bersamaan meningkatkan kedekatan emosional karyawan melalui peningkatkan komitmen organisasional.

Hasil dari pengujian signifikansi secara parsial (Uji-t) yang ditunjukkann pada Tabel 4, menunjukkan bahwa koefisien komitmen organisasi sebesar 0,023 dengan nilai probabilitas (nilai sig) 0,036. Nilai sig. $0.036<0.05$, sehingga dapat disimpulkan bahwakomitmen organisasi berpengaruh positif dan signifikan terhadap kinerja pegawai. Dengan demikian hipotesis yang diajukan adalah menerima $\mathrm{H}_{2}$.

Hubungan komitmen organisasi dengan kinerja Karyawan. Hasil analisis regresi linier berganda menunjukkan bahwa komitmen organisasi mempengaruhi secara positif terhadap kinerja karyawan. Komitmen merupakan integrasi dari perasaan kecintaan dan loyalitas yg tinggi dari pegawai kepada pekerjaannya atau perusahaannya. Pegawai yg memiliki komitmen tinggi terikat secara emosional (afektif), rasional (normatif), dan memiliki 
keinginan karir jangka panjang (kontinuan). Tiga komponen ini yg mendorong pegawai untuk bekerja secara optimal. Hasil temuan ini sejalan dengan penelitian sebelumnya bahwa komitmen organisasi mempengaruhi kinerja pegawai (Mandri et al., 2018), (Sunjaya et al., 2017), dan (Saryanto \& Amboningtyas, 2017).

\section{SIMPULAN}

Penelitiani ini bertujuan untuk mengkonfirmasi pengaruh budaya organisasi dan komitmen organisasi terhadap kinerja pegawai PT Garuda Indonesia Tbk. Hasil penelitian serta analisa pembahasan membuktikan bahwa budaya organisasi dan komitmen organisasi secara simultan berpengaruh terhadap kinerja pegawai. Hasil penelitian juga menunjukkan bahwa budaya budaya organisasi dan komitmen organisasi secara parsial berpengaruh positif dan signifikan terhadap kinerja pegawai.

Budaya organisasi dan komitmen organisasi merupakan faktor penting yang dapat menjelaskan variasi kinerja pegawai. Nilai-nilai budaya yang diyakini bersama dapat menjadi pengikat organisasi dengan pegawai. Dengan demikian, ikatan kuat tersebut dapat menimbulkan motivasi pegawai untuk meningkatkan kinerja pegawai dalam menyelesaikan pekerjaan secara maksimal. Komitmen merupakan integrasi dari perasaan kecintaan dan loyalitas yg tinggi dari karyawan kepada pekerjaannya atau perusahaannya. Komitmen tinggi yang dimiliki pegawai akan terikat secara emosional (afektif), rasional (normatif), dan memiliki keinginan karir jangka panjang (kontinuan), sehingga faktor-faktor tersebut yang dapat meningkatkan kinerja pegawai secara optimal.

Berdasarkan pembahasan dan hasil penelitian budaya organisasi dan komitmen organisasi terhadap kinerja pegawai di PT Garuda Indonesia Tbk., maka saran-saran yang dapat diberikan adalah sebagai berikut: Bagi Manajemen Kantor Pusat PT Garuda Indonesia (Persero) Tbk. Beberapa hal yang dapat dijadikan saran untuk meningkatkan kinerja pegawai, yaitu: (a) Perusahaan perlu memberikan kesempatan yang lebih besar kepada pegawai untuk memberikan ide-ide baru dan inovasi serta menghargai pengambilan resiko yang dilakukan oleh pegawai. Dengan memperhatikan hal tersebut diharapkan dapat meningkatkan juga dukungan pegawai terhadap perubahan-perubahan yang terjadi di dalam perusahaan, hal ini akan memperkuat budaya organisasi yang ada sehingga meningkatkan kinerja pegawai.

Berikut ini merupakan beberapa keterbatasan yang dimiliki dalam penelitian ini yaitu faktor-faktor yang mempengaruhi kinerja pegawai dalam penelitian ini hanya terdiri dari dua variabel, yaitu budaya organisasi dan komitmen organisasi. Sedangkan masih banyak faktor lain yang mempengaruhi kinerja pegawai, antara lain motivasi, pengembangan karir, kompensasi, gaya kepemimpinan, dan lain sebagainya.

\section{REFERENSI}

Aziz, A. (2018). Pengaruh Spiritualitas dan Budaya Organisasi Terhadap Kinerja Karyawan Resto Ayam Goreng Nelongso [University of Muhammadiyah 
Malang]. http:/ / eprints.umm.ac.id/39994/

Badan Pusat Statistik. (2016). Statistik Indonesia 2016. Badan Pusat Statistik Indonesia.

Direktorat Jenderal Perhubungan Udara Kementrian Perhubungan Republik Indonesia. (2017). Jumlah Maskapai Penerbangan Niaga Berjadwal di Indonesia. http://hubud.dephub.go.id/?id/aoc/index/filter:tahun,0;bulan,0;code,0

Eric, W., Intosh, M., \& Doherty, A. (2010). The influence of organizational culture on job satisfaction and intention to leave. Sport Management Review, 13, 106117.

Ibrahim, B. Z., Shurbagi., \& Ali., A. M. (2012). The Effect of Organizational Culture and the Relationship between Transformational Leadership and Job Satisfaction in Petroleum Sector of Libya. International Business Research, 5(9).

Javad, E., \& Davood, G. (2012). Organizational Commitment and Job Satisfaction. Journal of Science and Technology, 2(2).

Khaliq, I. (2015). Pengaruh Budaya Organisasi, Disiplin Kerja Dan Kepemimpinan Terhadap Kinerja Pegawai Pada Sekretariat Daerah Kabupaten Indragiri Hulu. Jurnal Tepak Manajemen Bisnis, 7(1), 76-91. https://ejournal.unri.ac.id/index.php/JTMB/article/viewFile/2659/2610

Luthans, F. (2012). Perilaku Organisasi. Andi Offset.

Mandri, A., Komara, A. H., \& David, D. (2018). Pengaruh Kepemimpinan, Komitmen, Budaya Organisai dan Motivasi Terhadap Kepuasan Kerja dan Kinerja Pegawai di Dinas Pekerjaan Umum Dan Penataan Ruang (Putr) Kabupaten Rokan Hilir. Procuratio: Jurnal Ilmiah Manajemen, 6(4), 421-441.

Mangkunegara, A. A. P. (2011). Manajemen Sumber Daya Manusia Perusahaan. Bandung: Rosda Karya.

Mangkunegara, A. A. P. (2013). Manajemen Sumber Daya Manusia Perusahaan. Bandung: Remaja Rosdakarya.

Mathis, R., \& Jackson, W. (2006). Human Resources Development (Track MBA series/terjemahan). Jakarta: Prestasi Pustaka.

Mega, K., \& Surya, U. (2016). Peran Knowledge Sharing Dalam Meperkuat Pengaruh Kompetensi Dan Rotasi Kerja Untuk Meningkatkan Kinerja Sdm (Studi Pada Dinas Koperasi dan UMKM Provinsi Jawa Tengah). http://repository.ut.ac.id/6587/

Okwa, A. (2011). Effects of Leadership Style on Organizational Performance: A Survey of Selected Small Scale Enterprises in Ikosi-Ketu Counsil Development Area of Lagos State, Nigeria. Australian Journal of Business and Management Research., 1(7), 100-111.

Ramadhan, T. (2017). Analisis Pengaruh Motivasi dan Komitmen Organisasi Terhadap Kinerja Karyawan Pada PT. XYZ. Jurnal Riset Manajemen Dan Bisnis (JRMB), 2(3), 353-362.

Robbins, S. (2015). Perilaku Organisasi. Jakarta: Salemba Empat.

Rosyidah, E., Fadah, I., \& Tobing, D. S. K. (2018). Pengaruh Kepuasan Kerja dan Budaya Organisasi Terhadap Kinerja Pegawai Melalui Komitmen Organisasi Di Unit-Unit Pelayanan Publik Kabupaten Jember. Jurnal Relasi Stie Mandala Jember, 14(1), 1-16.

Sabri, P. S., \& Ullah, M. I. (2012). Organizational Culture and Its Impact on the Job Satisfaction of the University Teachers of Lahore. International Journal of 
Business and Social Science, 2(24).

Saryanto., \& Amboningtyas, D. (2017). Pengaruh Rotasi Kerja, Stres, Kepuasan Kerja dan Komitmen Organisasi Terhadap Kinerja Karyawan (Studi Kasus Pada Ace Hardware Semarang). Journal of Management, 3(3), 1-10.

Seyyed, M. D. (2013). The correlate on between organizational culture and job satisfaction of employees in biotechnology production companies. European Journal of Experimental Biology, 3(5), 389-399.

Sinem, A., \& Asikgil, B. (2011). An Empirical Study of the Relationship Among Job Satisfaction, Organizational Commitment and Turnover Intention. International Review of Management and Marketing, 1(3), 43-53.

Sopiah, S. (2008). Budaya Organisasi, Komitmen Organisasional Pimpinan dan Pengaruhnya Terhadap Kepuasan Kerja dan Kinerja Karyawan Bank. Jurnal Keuangan Dan Perbankan, 12(2), 308-317.

Suharto, S., \& Nusantoro, J. (2018). The Relationship Among Managerial Capability, Organizational Citizenship Behavior, And Employee Performance: Mediation Effects Of Organizational Culture. Journal of Community Research and Service, 2(1), 168-175. file:///C:/Users/Hp 11/Downloads/9890-21170-1-PB.pdf

Sunjaya, O. P. A., Yulianeu, Y., Hasiholan, L. B., \& Syaifuddin, T. (2017). Pengaruh Budaya Kerja, Kemampuan dan Komitmen Organisasi Terhadap Kinerja Karyawan Bagian Produksi Pada PT. Phaprostbk Semarang. Journal of Management,

http://jurnal.unpand.ac.id/index.php/MS/article/viewFile/713/694

Sutrisno, S., Haryono, A. T., \& Warso, M. M. (2018). Pengaruh Kepuasan Kerja dan Komitmen Organisasi Terhadap Kinerja Karyawan Melalui Organizational Citizenship Behavior Sebagai Variabel Intervening (Studi Kasus Karyawan PT. Fumira Semarang). Journal of Management, 4(4).

Syed, A. (2010). Job Satisfaction and Organizational Commitment among Employees in the Sultanate of Oman. Psychology, 1(04), 295-299. https://doi.org/10.4236/psych.2010.14038

Taurisa, C. M., Djastuti, I., \& Ratnawati, I. (2012). Analisis pengaruh budaya organisasi dan kepuasan kerja terhadap komitmen organisasional dalam meningkatkan kinerja karyawan (Studi pada PT. Sido Muncul Kaligawe Semarang). Diponegoro University.

Tintami, L., Pradhanawati, A., \& Nugraha, H. S. (2013). Pengaruh Budaya Organisasi dan Gaya Kepemimpinan Transformasional Terhadap Kinerja Karyawan Melalui Disiplin Kerja Pada Karyawan Harian SKT Megawon II PT. Djarum Kudus. Jurnal Ilmu Administrasi Bisnis, 1(1), 189-196.

Victoria, B. (2010). Organizational culture as a predictor of job satisfaction: the role of gender and age. Emerald-Career Development International, 15(1).

Vincent, K. C., \& Dareen, M. J. (2007). Testing A Model Of The Antecendents And Consuquences Of Budgetary Participation On Job Performance. Accounting and Business Research, 37(1), 3-19.

Wibowo. (2012). Manajemen Kinerja. Jakarta: PT Raja Grafindo Persada.

Yousef, D. A. (2000). Organizational Commitment A Mediator of the Relationship of Leadership Behavior with Job Satisfaction and Performance in a nonwestern Country. Journal of Managerial Psychology, 15(1). 